JIA (Jurnal Ilmiah Akuntansi) • Vol. 6, No. 1, Hal: 85-101 • Juni 2021

\title{
Improving Firm Value through Intellectual Capital, Good Corporate Governance and Financial Performance
}

\author{
Maya Indriastuti*, Indri Kartika \\ Universitas Islam Sultan Agung, Л. Kaligawe Raya No. 4, Kota Semarang, Jawa \\ Tengah, Indonesia \\ *(maya@unissula.ac.id)
}

Riwayat Artikel:

Tanggal diajukan:

10 Januari 2021

Tanggal diterima:

21 Mei 2021

Tanggal dipublikasi daring: 25 Mei 2021

Keywords: financial performance; firm value; good corporate governance; intellectual capital; Jakarta Islamic Index.

\section{Pengutipan:}

Indriastuti, Maya \& Kartika, Indri. (2021). Improving Firm Value through Intellectual Capital, Good Corporate Governance and Financial Performance. JIA (Jurnal Ilmiah Akuntansi), Vol. 6, No. 1, Hal: 85-101.

Kata Kunci: good corporate governance; intellectual capital; Jakarta Islamic Index; kinerja keuangan; nilai perusahaan

\section{ABSTRACT}

This study analyzed and tested empirically the firm value improvement through intellectual capital, good corporate governance, and financial performance. The samples of this study comprised 90 companies that analyzed by using the Structural Equation Model based on Partial Least Square with WrapPLS software. The results indicated that intellectual capital, good corporate governance, and financial performance were able to improve the firm value. The financial performance also was able to mediate the effect of intellectual capital and good corporate governance on firm value. The findings may become a consideration for regulators, especially the Financial Services Authority in making a a complete and strong regulation regarding the implementation of good corporate governance; as well as for investors to invest in companies listed on the Jakarta Islamic Index.

\section{ABSTRAK}

Penelitian ini menganalisis dan menguji secara empiris peningkatan nilai perusahaan melalui modal intelektual, tata kelola perusahaan yang baik, dan kinerja keuangan. Sampel penelitian ini berjumlah 90 perusahaan yang dianalisis dengan menggunakan Structural Equation Model berbasis Partial Least Square dengan software WrapPLS. Hasil penelitian menunjukkan bahwa modal intelektual, tata kelola perusahaan yang baik, dan kinerja keuangan mampu meningkatkan nilai perusahaan. Kinerja keuangan juga mampu memediasi pengaruh modal intelektual dan tata kelola perusahaan yang baik terhadap nilai perusahaan. Temuan ini dapat menjadi pertimbangan bagi regulator khususnya Otoritas Jasa Keuangan dalam membuat regulasi yang lengkap dan kuat mengenai penerapan tata kelola perusahaan yang baik dan juga investor untuk berinvestasi pada perusahaan yang terdaftar di Jakarta Islamic Index. 


\section{INTRODUCTION}

The weakening of the Jakarta Islamic Index's stock price continues to be even steeper in 2020 along with the composite stock price index. Based on Bloomberg 2020 data, the Jakarta Islamic Index closed at the level of 406.51 with a fall of $6.44 \%$ or 27.98 points from the previous closing level. During trading, the Jakarta Islamic Index moved at the level of 404.91-434.3. 28 out of 30 stocks traded in JII were weak, while the other 2 stocks were able to rise. The shares of PT Telekomunikasi Indonesia (Persero) Tbk and PT Unilever Indonesia Tbk, which fell 6.76 percent and 6.61 percent, respectively, became the main stressors for the weakening of the Jakarta Islamic Index. In line with the Jakarta Islamic Index, the Composite Stock Price Index closed at 4,105.42 with a sharp decline of $5.20 \%$ or 225.25 points from the previous closing level. All sectors ended in negative territory, led by various industries $(-6.07 \%)$, consumer goods $(-5.95 \%)$, and basic industries ($5.92 \%)$. The weakening of the stock price index affects the firm value listed on the Jakarta Islamic Index.

Firm value is a collection of values that become the basis and foundation of the company in shaping the systems, processes, policies, and strategies in running the company (Aboud and Diab, 2018) where the firm value becomes the basis for achieving short-, medium-, and longterm goals. Firm value is also a tool of individual (employee) or shared goal. Ardie and Simanungkalit (2014) added that firm value is also a belief instilled in an organizational structure that can break the boundaries of objects, people, and situations. Therefore, along with the economic changes characterized by a sciencebased economy with the application of knowledge management, the prosperity of companies will depend on the attainment of transformation and capitalization of knowledge itself. The application of knowledge-based business will change the creation of firm value This firm value creation can be realized through intellectual capital, good corporate governance, and financial performance.

Intellectual capital is a concept that can give new knowledge-based resources and describe intangible assets. If it is used optimally, it allows the company to carry out its strategy effectively and efficiently (Belkaoui, 2005) (Riahi-belkaoui \& Riahibelkaoui, 2005). Bchini (2015); Deep and Narwal (2014); Janosevic and Dzenopoljac (2015); Kamath (2015); Kharal, et al., (2014); Nuryaman (2015); Ozkan, et al., (2016); Ranani 
and Bijani (2014); Riad (2017); Sardo and Serrasqueiro (2017); Venugopal and Subha (2015); Vladimir, et al., (2017) revealed that good management of intellectual capital can improve the company's ability to manage assets and improve the company's financial performance to create firm value. In contrast, Holienka and Pilkova (2014) argued that intellectual capital has no significant positive effect on financial performance.

Good corporate governance is the practice of authority over the company entities (Fung, 2014). The better the company implements good corporate governance, the better the value of the company. Corporate governance can support the fulfillment of the shareholders' or stakeholders' right to obtain reliable, accurate, and timely information. Besides, it also shows the importance of company management in disclosing all financial performance information independently, accurately, on time, and transparently. The implementation of good corporate governance give a good contribution to the company's financial performance and firm value Mukhtaruddin, et al., (2014). Ararat, et al., (2016); Ardie and Simanungkalit (2014) stated that good corporate governance has a positive and significant effect on firm value.

Financial performance is an analysis to measure the extent of a company has implemented proper and correct rules. Financial performance is an aspect that can assess the company's ability in earning profits and result in company sustainability (Ang, 1997). Nuryaman (2015) argued that the higher the profit generated, the higher the firm value will be. Dianawati and Siti (2016), Sudibya et al., (2014), Tjandrakirana and Monica (2014) proved that profitability has a positive effect on firm value. It means, increased profitability (ROA) can increase the company's stock price so that it will improve the firm value.

Based on the description above, this study analyzed and tested empirically whether or not the financial performance can moderate the effect of intellectual capital and good corporate governance on the firm value listed in the Jakarta Islamic Index. The researchers chose Jakarta Islamic Index Index as the research's object is because the Jakarta Islamic Index is one of the lists of stock indexes on the Indonesia Stock Exchange. It calculates an average index of 30 stocks that meet the criteria of sharia, have the largest market capitalization and have a high level of trading value liquidity. 
(www.idx.co.id). The study contributes to (1) company managers to manage their resources effectively so they can provide value to the company; (2) regulators, in this case, is the Financial Services Authority, to make detailed and strong regulations regarding the implementation of good corporate governance; and (3) for investors, serve as a guide in making investment decisions.

\section{LITERATURE REVIEW AND HYPOTHESIS DEVELOPMENT}

\section{Stakeholder Theory}

Stakeholder theory is a theory that describes which parties the company is responsible for (Freeman, 1984). The company must maintain relationships with its stakeholders by accommodating the desires and needs of its stakeholders who have power over the availability of resources used for the company's operational activities. The resources are such as labor, markets for the company's products, and others (Ghozali and Chariri, 2016).

\section{Agency Theory}

Agency theory is the relationship between shareholders as principal and management as an agent (Jensen and Meckling, 1976). Agency theory assumes that managers and shareholders tend to have different interests causing conflict within the company. This conflict arises because managers tend to prioritize the interests of the company and sacrifice the interests of shareholders. This conflict can be minimized by implementing good and consistent corporate governance (Jensen and Meckling, 1976).

\section{Intellectual Capital}

Intellectual capital is a resource of a company that can provide a competitive advantage for the company. It also uses to develop and implement the company's strategy to improve the company's performance. (Stewart, 1997). Gunawan and Tartila (2017) added that intellectual capital is considered as an asset in a company based on knowledge. It becomes the basis of the company's competence which can affect the company's development and excellence. Pulic (1998) divided intellectual capital into three components, namely human capital, structural capital, customer capital. If these three components are fully utilized, they can create added value for the company. Moreover, it helps to increase the stock value of the company.

\section{Good Corporate Governance}

Corporate Governance Indonesia forum (2001) argued that corporate 
governance is a set of rules governing the relationship between shareholders, company managers, creditors, government, employees, and other internal and external stakeholders. The rules with regard to rights and obligations, or in other words a system that regulates as well as controlling the company. The expected goals of a company can be realized by managing organizational resources efficiently, effectively, and productively with the principles of openness, accountability, responsibility, independence, and fairness.

\section{Financial Performance}

Financial performance is an analysis to measure the extent of a company has implemented proper and correct rules (Ang, 1997). Financial performance is an aspect that can assess the company's ability in earning profits and result in company sustainability. The measurement of financial performance in this study uses return on assets, namely the ratio of net income to total assets (Ang, 1997). Return on assets refers to profitability and operational efficiency. It is used to compare the company's business performance to competitors and similar industries.

\section{Firm Value}

The firm value is the price paid by the prospective buyer which benefits the company for sale (Fama, et al., 1998). Smithers and Wright (2008) suggested that the firm value can be determined using Tobin's $Q$ ratio. This is the ratio of the equity value plus the market value of the company's debt. Companies that have Tobin's $Q$ with a higher value indicating the better company's growth prospects. It is because investors will sacrifice more for companies that have a market value of assets that is greater than their book value. On the other hand, if the value of $Q$ is less than 1 , it means that the investment in the asset is not attractive.

\section{Intellectual Capital and Financial Performance}

Pulic (1998) intellectual capital disclosure covers the sum of what is produced by the three main elements of the organization. Those are produced with the knowledge and technology that give the company a higher value of the organization's competitive advantages. Intellectual capital can improve the company's finances, both in the short and long term. Therefore, company management must be able to manage its physical and intellectual resources 
maximally to create added value for the company (Deegan, 2004). Deep and Narwal (2014); Holienta and Pilkova (2014); Kharal et al., (2014); Ranani and Bijani (2014); Janosevic and Dzenopoljac (2015); Kamath (2015); Nimtrakoon (2015); Nuryaman (2015); Venugopal and Subha (2015); Ozkan et al., (2016); Gunawan and Tartila (2017); Riad (2017); Sardo and Serrasqueiro (2017); Vladmir et al., (2017); Chowdhury, et al., (2018) suggested that intellectual capital has a positive effect on financial performance.

$\mathrm{H}_{1}$ : Intellectual capital has positive effect on financial performance

\section{Good Corporate Governance and Financial Performance}

Good corporate governance is a set of regulations governing the relationship between shareholders, company managers, creditors, government, employees, and other internal and external stakeholders regarding their rights and obligations (Corporate Governance Indonesia Forum, 2001). The implementation of good governance will minimize agency conflicts, as the result, it improves the company's financial performance for the better. Mahrani and Soewarno (2018); Kabir and Thai (2017); Ararat, et al., (2016) found that good corporate governance has positive effect on financial performance.

$\mathrm{H}_{2}$ : Good corporate governance has positive effect on financial performance

\section{Intellectual Capital and Firm Value}

Intellectual capital is a concept that gives new knowledge-based resources and describes intangible assets which, if used optimally, allow a company to carry out its strategy effectively and efficiently (Belkaoui, 2003). Based on the stakeholder theory, company management must be able to fully manage its physical and intellectual resources to create added value for the company (Deegan, 2004). This indicates that good resource management can increase productivity within the company. Thus, it has an impact on improving the firm value. Aboud and Diab (2018); Bchini, B. (2015); Nuryaman (2015); Liang et al., (2011) indicated that intellectual capital has positive effect on firm value.

$\mathrm{H}_{3}$ : Intellectual capital has positive effect on firm value

\section{Good Corporate Governance and Firm Value}

Good corporate governance is the practice of authority over corporate 


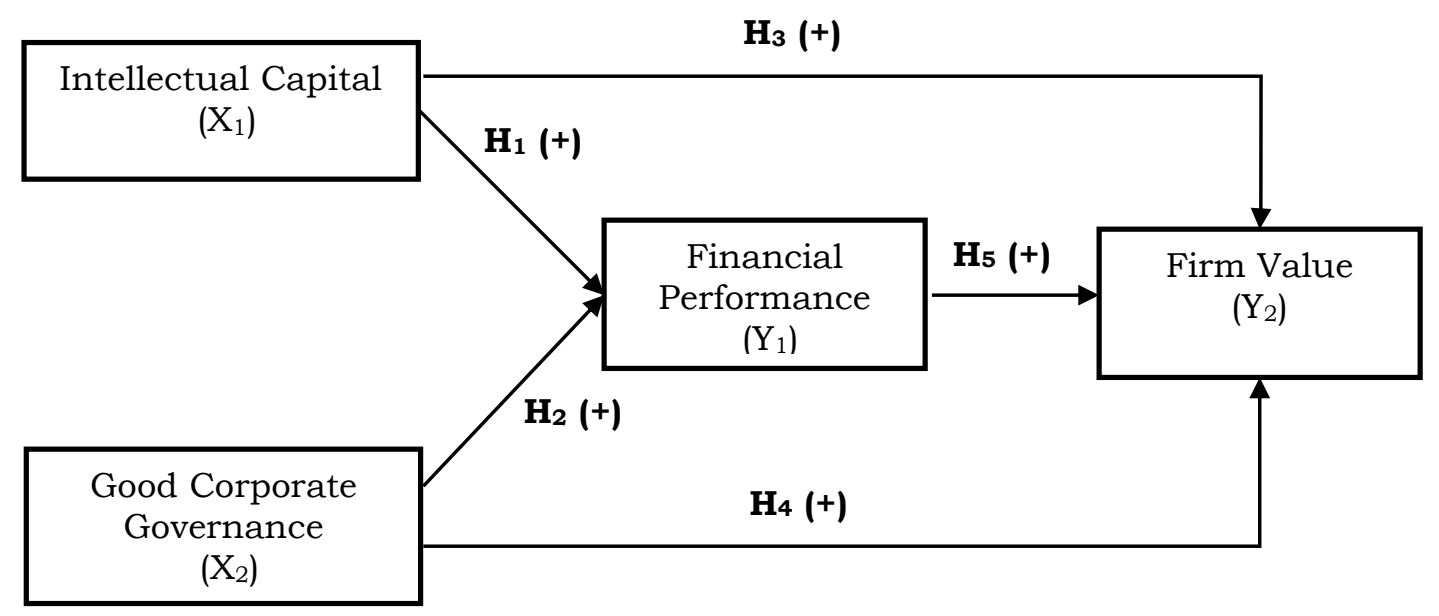

Figure 1. Research Model

corporate entities (Fung, 2014). The implementation of good corporate governance in a company can make the company's image better. The company has to apply the basic principles of good corporate governance such as transparency, accountability, responsibility, independence, and honesty to reduce conflicts between management and company owners. Management as the agent. will work under the rules or regulations of the company. Aboud and Diab (2018); Ararat et al., (2016); Mukhtaruddin, et al., (2014); Liang et al., (2011) stated that good corporate governance has positive and significant effect on firm value.

$\mathrm{H}_{4}$ : Good corporate governance has positive effect on Firm Value

\section{Financial Performance and Firm Value}

Financial performance is an aspect that can assess the extent of a company's ability to earn profits and result in a sustainable company (Ang, 1997). Stakeholder theory considers accounting profit as only a measure of return for shareholders. This is supported by Dianawati and Siti (2016), Nuryaman (2015); Sudibya et al., (2014), Tjandrakirana and Monica (2014) who proved that profitability has positive effect on firm value.

$\mathrm{H}_{5}$ : Financial performance has positive effect on firm value.

\section{METHOD}

\section{Population and Sample}

The population in this study comprised all companies listed on the Jakarta Islamic Index 2017-2019. The sampling method in this study was purposive sampling with the following criteria; Jakarta Islamic Index companies that publish complete annual reports and good corporate governance reports regarding the research data. 
Table 1. Variable and Indicator

\begin{tabular}{|c|c|c|c|}
\hline No & Variable & $\begin{array}{c}\text { Operational } \\
\text { Definition }\end{array}$ & Measurement \\
\hline \multicolumn{4}{|c|}{ Dependent Variable } \\
\hline & Firm Value & $\begin{array}{l}\text { The available price is } \\
\text { paid by the prospective } \\
\text { buyer when the } \\
\text { company is sold }\end{array}$ & $\begin{array}{l}\text { Tobins } Q \rightarrow \text { comparing the market } \\
\text { value of the company with the } \\
\text { replacement cost of the company's } \\
\text { assets } \\
\text { (Smithers and Wright, 2007). }\end{array}$ \\
\hline \multicolumn{4}{|c|}{ Independent Variable } \\
\hline 1 & $\begin{array}{l}\text { Intellectual } \\
\text { Capital }\end{array}$ & $\begin{array}{l}\text { Resources in the form } \\
\text { of knowledge available } \\
\text { to the company that } \\
\text { produce high-value } \\
\text { assets and future } \\
\text { economic benefits for } \\
\text { the company (Steward, } \\
\text { 1997). }\end{array}$ & $\begin{array}{l}\text { VAIC model (Value Added } \\
\text { Intellectual Capital) developed by } \\
\text { Pulic (1998) } \\
\text { VAIC stages: } \\
\text { (1) Value Added (VA) = OUT- IN } \\
\text { (2) Value Added Capital Employed } \\
\text { (VACA) = VA/CE } \\
\text { (3) Value Added Human Capital } \\
\text { (VAHU) = VA/HC } \\
\text { (4) Structural Capital Value Added } \\
\text { (STVA) = SC/VA } \\
\text { (5) VAIC = VACA + VAHU + STVA } \\
\text { Information: } \\
\text { OUT (Output) = Total sales and } \\
\text { other income } \\
\text { IN (input) = Expenses other than } \\
\text { employees' expenses } \\
\text { CE (Capital Employed) = Available } \\
\text { funds (ekuitas, laba bersih) } \\
\text { HC (Human Capital) = Labor load } \\
\text { (total salary, wages and employees' } \\
\text { income) } \\
\text { SC (Structural Capital) = VA-HC }\end{array}$ \\
\hline & $\begin{array}{l}\text { Good Corporate } \\
\text { Governance }\end{array}$ & $\begin{array}{l}\text { A practice of authority } \\
\text { over corporate entities } \\
\text { (Fung, 2014) }\end{array}$ & $\begin{array}{l}\text { GCG Score, is: } \\
\text { a) Shareholders } \\
\text { (Subindex A), the scoring of } \\
\text { shareholders rights; } \\
\text { Boards of Directors (Subindex } \\
\text { B), the scoring of } \\
\text { commissioner board; } \\
\text { Outside Directors (Subindex } \\
\text { C), the scoring of independent } \\
\text { commissioner; } \\
\text { d) Audit Commitee and Internal } \\
\text { Auditor (Subindex D), the } \\
\text { scoring of audit committee } \\
\text { and internal auditor; } \\
\text { Disclosure to Investor } \\
\text { (Subindex E), the scoring on } \\
\text { disclosure to investor. } \\
\text { Each measure in the subindex is } \\
\text { given } 1 \text { point if fulfilled and 0 if not } \\
\text { (Black, et al, 2003). }\end{array}$ \\
\hline
\end{tabular}




\begin{tabular}{llll}
\hline No & Variable & \multicolumn{1}{c}{$\begin{array}{c}\text { Operational } \\
\text { Definition }\end{array}$} & Measurement \\
\hline Intervening Variable & \multicolumn{1}{c}{ A ratio used to assess } \\
\hline 1 & $\begin{array}{l}\text { Financial } \\
\text { Performance }\end{array}$ & $\begin{array}{l}\text { the ability of company } \\
\text { management to get ROA }=\end{array}$ & Net Profit \\
overall profit & Source: Ang (1997) \\
\hline
\end{tabular}

Table 2. Descriptive Statistic

\begin{tabular}{cccc}
\hline \multicolumn{4}{c}{ Minimum and Maximum Values } \\
\hline IC & GCG & ROA & TOBINS Q \\
0.18 & 9.60 & 0.12 & 0.15 \\
9.88 & 17.10 & 2.49 & 33.89 \\
\hline
\end{tabular}

\section{Data Analysis Technique}

The data analysis technique used in this study was the Structural Equation Model based on Partial Least Square (SEM-PLS) with WrapPLS software.

\section{RESULT AND DISCUSSION}

\section{Descriptive Statistic Analysis}

Table 2 shows the results that have been processed by descriptive statistical tests. It indicates that the intellectual capital variable has a minimum value of 0.18 and a maximum value of 9.88. Good corporate governance has a minimum value of 9.60 and a maximum value of 17.10. Financial performance with the ROA indicator has a minimum value of 0.12 and a maximum value of 2.49 . Meanwhile, the firm value with the Tobins $\mathrm{Q}$ indicator has a minimum value of 0.15 with a maximum value of 33.89.

\section{Measurement Model Evaluation (Outer Model)}

Outer Model is found through 3 criteria, namely convergent validity, discriminant validity, and composite reliability. The following are the results of data processing:

a. Convergent Validity

Convergent Validity of the measurement model can be seen from the correlation between the indicator score and the construct score. The criteria for the valid loading factor value of each indicator is greater than 0.70. Furthermore, the $\mathrm{p}$-value has to reach $<0.05$ to be considered as significant, the limit value for AVE is 0.050 and composite reliability is 0.50 . 
Table 3. Convergent Validity

\begin{tabular}{lcccccr}
\hline & IC & GCG & ROA & TOBINS Q & SE & P value \\
\hline IC & 1.000 & 0.000 & 0.000 & 0.000 & 0.087 & $<0.001$ \\
GCG & 0.000 & 1.000 & 0.000 & 0.000 & 0.087 & $<0.001$ \\
ROA & 0.000 & 0.000 & 1.000 & 0.000 & 0.087 & $<0.001$ \\
TOBINS Q & 0.000 & 0.000 & 0.000 & 1.000 & 0.087 & $<0.001$ \\
\hline
\end{tabular}

Table 4. Average Variances Extracted

\begin{tabular}{lccr}
\hline IC & GCG & ROA & TOBINS Q \\
\hline 1.000 & 1.000 & 1.000 & 1.000 \\
\hline
\end{tabular}

Table 5. Discriminant Validity

\begin{tabular}{llllc}
\hline & IC & GCG & ROA & TOBINS Q \\
\hline IC & 1.000 & 0.308 & 0.373 & 0.620 \\
GCG & 0.308 & 1.000 & 0.352 & 0.576 \\
ROA & 0.373 & 0.352 & 1.000 & 0.339 \\
TOBINS Q & 0.620 & 0.576 & 0.339 & 1.000 \\
\hline
\end{tabular}

Table 6. Composite Reliability

\begin{tabular}{cccc}
\hline \multicolumn{4}{c}{ Composite Reliability Coefficients } \\
\hline IC & GCG & ROA & TOBINS Q \\
1.000 & 1.000 & 1.000 & 1.000 \\
\hline \multicolumn{4}{l}{ Cronbach's Alpha Coefficients } \\
\hline 1.000 & GCG & ROA & TOBINS Q \\
\hline
\end{tabular}

Based on the results of the average variance extracted

(AVE)

measurement, it shows that the AVE value has a value of $>0.50$. This proves that all constructs are good so that it fulfills the validity requirements.

\section{b. Discriminant Validity}

Discriminant Validity is assessed from the cross-loading measurement with the construct. It can be seen through the latent loading construct which will predict the indicator better than other constructs. Based on the results of the discriminant validity measurement above, which is seen through the cross-loadings value, it shows that each construct with its indicator has a higher cross loading value than other constructs. Therefore, the constructs in this study are able to predict their indicators better than other indicators.

c. Composite Reliability

A composite reliability test is utilized to assess the reliability of indicators of a latent construct with a Cronbach's alpha value above 0.70 . Table 6 presents the results of cross loading output, composite reliability, 
Table 7. The Results of the R-Square Determination Coefficient Test $\left(R^{2}\right)$

\begin{tabular}{|c|c|c|c|}
\hline \multicolumn{4}{|c|}{ R-Squared Coefficients } \\
\hline IC & GCG & $\begin{array}{c}\text { ROA } \\
0.261\end{array}$ & $\begin{array}{c}\text { TOBINS Q } \\
0.490\end{array}$ \\
\hline \multicolumn{4}{|c|}{ Adjusted R-Squared Coefficients } \\
\hline IC & GCG & $\begin{array}{c}\text { ROA } \\
0.244\end{array}$ & $\begin{array}{c}\text { TOBINS Q } \\
0.481\end{array}$ \\
\hline
\end{tabular}

Table 8. Effect Sizes for Path Coefficients

\begin{tabular}{ccccc}
\hline & IC & GCG & ROA & TOBINS Q \\
\hline ROA & 0.169 & 0.122 & & \\
TOBINS Q & 0.205 & 0.273 & 0.140 & \\
\hline
\end{tabular}

and Cronbach's alpha. Based on the results of the composite reliability measurement through the value of composite reliability and Cronbach's alpha, it shows that the value of each construct is $>0.70$. It means all constructs are good so they fulfill the reliability requirements.

\section{Inner Model Test Results (Structural Model)}

a. Determination Coefficient (R2)

The $\mathrm{R}^{2}$ test uses to explain the effect of certain exogenous latent variables on endogenous latent variables whether they have a substantive effect or not. The R2 test can explain endogenous variables if the value is close to 1 . The following are the results of the R-Square (R2) output:

Based on the results of the measurement on the R-square determination coefficient (R2), it shows that firm value can be explained by intellectual capital, good corporate governance, and company performance by 49\%. Meanwhile, 51\% are explained by other variables outside the variables studied. The value of the $R$-square adjuster coefficient (adj R2) shows that firm value can be explained by intellectual capital, good corporate governance, and company performance by $48.1 \%$. The $51.9 \%$ are explained by other variables outside the variables studied.

\section{b. Hypothesis Test Results}

The following is a picture of the research results from the effect size based on data processing. Intellectual capital variable has a significant positive effect on financial performance. This can be observed through the path coefficient value which is quite large for 0.22 with a $\mathrm{p}$ value $\leq 0.05$, thus $\mathrm{H} 1$ is accepted. The coefficient of 0.22 indicates that if there is an increase in intellectual capital, the financial performance wi 


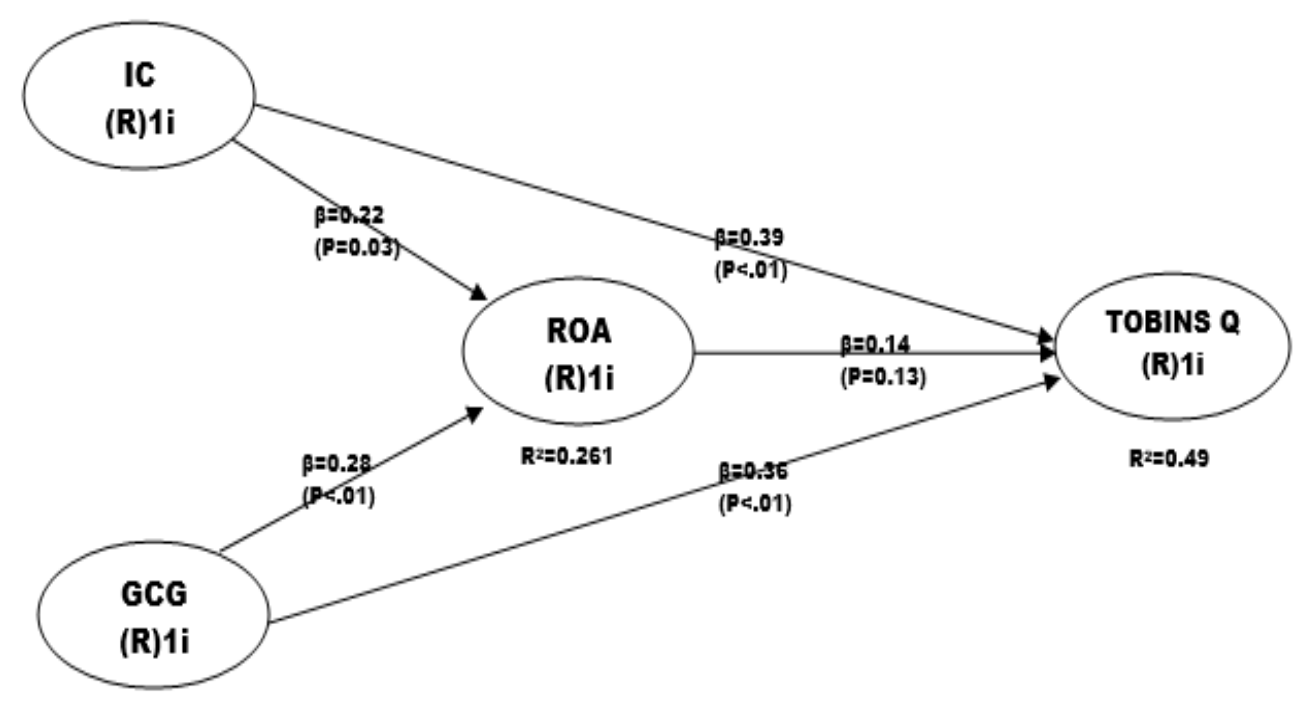

Figure 2. WrapPLS Result

increase by 0.22 and vice versa. The effect size value shows 0.169. It means the intellectual capital variable affects financial performance by $16.9 \%$ and the remaining $83.1 \%$ is influenced by other variables.

Good corporate governance variable has a significant positive effect on financial performance. It is reflected through the path coefficient value which is quite large for 0.28 with a p-value $\leq$ of 0.05 so that $\mathrm{H} 2$ is accepted. The coefficient of 0.28 indicates that if there is an increase in good corporate governance, the financial performance will increase by 0.28 and vice versa. The effect size value of 0.122 means that the green investment variable affects financial performance by $12.2 \%$ and the remaining $87.8 \%$ is influenced by other variables.

The intellectual capital variable has a significant positive effect on firm value. This is shown by the path coefficient value which is quite large for 0.39 with a $p$-value $\leq$ of 0.05 , then H3 is accepted. The coefficient of 0.39 indicates that if there is an increase in intellectual capital, the company value will increase by 0.39 and vice versa. The effect size value of 0.205 means that the intellectual capital variable affects the company value by $20.5 \%$ and the remaining $79.5 \%$ is influenced by other variables.

Good corporate governance variable has a significant positive effect on firm value. This is proven by the path coefficient value which is quite large for 0.36 with a $\mathrm{p}$-value $\leq$ of 
0.05, therefore $\mathrm{H} 4$ is accepted. The coefficient of 0.36 indicates that if there is an increase in good corporate governance, the company value will increase by 0.36 and vice versa. The effect size value of 0.273 means that the variable good corporate governance affects firm value by $27.3 \%$ and the remaining $72.7 \%$ is influenced by other variables.

Financial performance variables have a significant positive effect on firm value. This is shown by the path coefficient value which is quite large for 0.14 with a p-value $\leq$ of 0.05 . Consequently, $\mathrm{H} 5$ is accepted. The coefficient of 0.14 indicates that if there is an increase in financial performance, the company value will increase by 0.14 and vice versa. The effect size value of 0.140 means that the financial performance variable affects the firm value by $14 \%$ and the remaining $86 \%$ is influenced by other variables.

\section{Discussion}

Intellectual Capital and Financial Performance

Intellectual capital has a positive and significant effect on financial performance as measured by return on assets. These results indicate that the greater the intellectual capital, the greater the financial performance. This means that the Jakarta Islamic
Index company management has succeeded in managing its physical and intellectual resources maximally so that it can create added value for the company in form of increased company revenue and profit (Deegan, 2004). Pulic (1998) stated that intellectual capital is able to increase the company's financial both in the short and long term. This becomes the benchmark of a company's success. A good company's financial performance is not only measured based on the amount of tangible assets owned by the company, but in this digitalization era, intellectual capital also plays a crucial role. The results of this study are consistent with the study (2014); Ranani and Bijani (2014); Janosevic and Dzenopoljac (2015); Kamath (2015); Nimtrakoon (2015); Nuryaman (2015); Venugopal and Subha (2015); Ozkan et al., (2016); Gunawan and Tartila (2017); Riad (2017); Sardo and Serrasqueiro (2017); Vladmir et al., (2017); Chowdhury, et al. (2018) who stated that intellectual capital has positive effect on financial performance.

Good Corporate Governance and Financial Performance

Good corporate governance affects the financial performance positively as measured by return on assets. In other words, the 
implementation of good corporate governance in the Jakarta Islamic Index company has gone well so that it can improve the company's financial performance. This is also depicted by the management of organizational resources that runs effectively, economically or productively (Deep and Narwal 2014) Holienta and Pilkova (2014); Kharal et al., (2014) with transparent, accountable, responsible independent, and fair principles. As the result, it minimizes agency conflicts and improves the company's financial performance. The results of this study are in line with the study of Mahrani and Soewarno (2018); Kabir and Thai (2017); Ararat, et al., (2016). They succeeded in proving that good corporate governance has a positive effect on financial performance.

\section{Intellectual Capital and Firm Value}

Intellectual capital affects the firm value positively and significantly as measured by Tobin's Q. This means that the higher the intellectual capital (knowledge and technology) owned by the company, the higher the value of a company. Intellectual capital is a concept that can provide new knowledge-based resources and describe intangible assets, in which if it is used optimally, it allows a company to carry out its strategy effectively and efficiently (Belkaoui, 2003). The results of the study are similar to stakeholder theory. The management of the company must be able to manage its physical and intellectual resources maximally to create added value for the company (Deegan, 2004). The resources management can increase productivity in companies, especially companies listed on the Jakarta Islamic Index. Accordingly, it has an impact on improving firm value. Aboud and Diab (2018); Bchini, B. (2015); Nuryaman (2015); Liang et al., (2011) supported this result that intellectual capital can improve the firm value.

Good Corporate Governance and Firm Value

Good corporate governance plays a positive and significant role in firm value as measured by Tobin's $Q$. Particularly, the implementation of good corporate governance in the company Jakarta Islamic Index has gone well. This is because good corporate governance is a practice of authority over corporate entities (Fung, 2014). Thereupon the implementation will create a better corporate image because the Jakarta Islamic Index company has implemented the basic principles of good corporate governance such as 
transparency, accountability, responsibility, independence, and honesty for the benefit of shareholders, stakeholders, and society. Thus agency conflicts that occur between agents, stakeholders, shareholders, and the community can be minimized. Aboud and Diab (2018); Ararat et al., (2016); Mukhtaruddin, et al., (2014); Liang et al., (2011) suggested the similar result that good corporate governance has positive and significant effect on firm value.

Financial Performance and Firm Value

Financial performance affects the firm value positively and significantly as measured by Tobin's Q. This means that the higher the financial performance, the higher the firm value. This financial performance illustrates that the Jakarta Islamic Index company can earn profits so that it attracts investors to invest in the Jakarta Islamic Index company. This is because investors believe companies that have good financial performance will provide high returns and show that the Jakarta Islamic Index company can keep the company going. In line with the stakeholder theory that accounting profit is only a measure of return for shareholders, value-added is a more accurate measure created by stakeholders and then distributed to the same stakeholders (Meek dan Gray, 1988). The study of Dianawati and Siti (2016), Nuryaman (2015); Sudibya et al., (2014), Tjandrakirana and Monica (2014) proved that the increase in profitability (ROA) can also increase the company's stock price. As the result, the firm value will be improved.

\section{CONCLUSION, IMPLICATION AND LIMITATION}

The results of the study based on data processing show that intellectual capital, good corporate governance, and financial performance play a positive and significant effect on firm value. Furthermore, financial performance can mediate the effect of intellectual capital and good corporate governance on entrepreneurial value. The results of this study contribute to: (1) company managers. It can be a reference for managing their resources effectively so it provides value to the company; (2) regulators, especially the Financial Services Authority in making comprehensive and strong regulations regarding the implementation of good corporate governance, and (3) investors, to be the guideline of investment in companies listed on the Jakarta Islamic Index. 
However, this study has several limitations, including: intellectual capital, good corporate governance, and financial performance variables that explain the firm value of $48.1 \%$. Therefore, the suggestions for further research are (a) add other variables as independent variables such as corporate social responsibility, intervening variables such as company reputation; (b) use other measures for financial performance and good corporate governance. Financial performance can use other proxies, such as return on equity or return on investment. Meanwhile, the good corporate governance uses other proxies such as the principles, mechanisms, and structures of good corporate governance; and (c) add research objects to companies listed on the Indonesian Sharia Stock Index.

\section{REFERENSI}

Ararat, M., Black, B. S., \& Yurtoglu, B. B. (2016). The Effect of Corporate Governance Value and Profitability: Time-Series Evidence From Turkey. Emerging Markets Review, 20-30. https://doi.org/10.1016/j.emem ar.2016.10.001

Ardie, $\mathrm{P}$ and Simanungkalit, R. M. (2014). The Impact of Implementation of Good Corporate Governance to Firm Value (Evidence From Indonesia Public Banking Sector). Review of Integrated Business and Economics Research, 4(December 1998), 95-102.
Bchini, B. (2015). Intellectual Capital and Value Creation in the Tunisian Manufacturing Companies. Procedia Economics and Finance, 23(October 2014), 783-791. https://doi.org/10.1016/S22125671(15)00443-8

Deep, R. and Narwal, K. P. (2014). "Intellectual Capital and its Association with Financial Performance: A study of Indian Textile Sector." International Journal Management, Business Research, 4(1), 43-54.

Fung, B. (2014). The Demand and Need for Transparency and Disclosure in Corporate Governance. 2(2), 72-80. https://doi.org/10.13189/ujm.2 014.020203

Holienka, M., and Pilkova, A. (2014). Comparing impact of Intellectual Capital on firm performance before and after crisis. Proceeding of The 6th European Conference on Intellectual Capital (ECIC).

Janosevic, S. and Dzenopoljac, V. (2015). "The impact of Intellectual Capital on Companies' Market Value and Financial Performance". Ekonomika Preduzeca, 354-371.

Kamath, B. G. (2015). "Impact of intellectual capital on financial performance and market valuation of firms in India." International Letters of Social and Humanistic Sciences, 48, 107122.

Khan, A. M.h and Raushan, M. A. (2017). "An empirical study of the impact of intellectual capital on Indian IT Industry."

Kharal, M., Rehman, M. Z., Abrar, M., Khan, M. S. and Kharal, M. 
(2014). "Intellectual capital and firm performance: An empirical study on the Oil and Gas sector of Pakistan." International Journal of Accounting and Financial Reporting, 4(1), 238-261.

Mukhtaruddin, Relasari, and M. F. (2014). Good Corporate Governance Mechanism , Corporate Social Responsibility Disclosure on Firm Value: Empirical Study on Listed Company in Indonesia Stock Exchange. International Journal of Finance and Accounting Studies, 2(1), 1-10. https://doi.org/10.7575/aiac.ijfa s.v.2n.1p. 1

Naranjo-Gil, D., \& Hartmann, F. (2007). Management Accounting Systems, Top Management Team Heterogeneity and Strategic Change. Accounting, Organization and Society, 32, 735-756.

Nuryaman. (2015). The Influence of Intellectual Capital on The Firm ' $s$ Value with The Financial Performance as Intervening Variable. Procedia - Social and Behavioral Sciences, 211(September), 292-298. https://doi.org/10.1016/j.sbspro .2015 .11 .037

Ozkan, N., Cakan, S., and Kayacan, M. (2016). "Intellectual Capital and Financial Performance: A Study of the Turkish Banking Sector."

Ranani, H. S. and Bijani, Z. (2014). "The impact of intellectual capital on financial performance of Listed companies in Trehan Stock Exchange." International Journal of Academic Research in Accounting, Finance and Management Sciences, 4(1), 119127.

Riad Ahmad, M. A. (2017). "The
Impact of Intellectual Capital Dimensions on Organizational Performance of Public Hospitals in Jordan". Global Journal of Management and Business Research: Administration and Management, 17(5).

Riahi-belkaoui, A., \& Riahi-belkaoui, A. (2005). multinational firms: A study of the resource-based and stakeholder views Intellectual capital and firm performance of US multinational firms $A$ study of the resource-based and stakeholder views. https: //doi.org/10.1108/146919 30310472839

Sardo, P. and Serrasqueiro, Z. (2017). "A European Empirical Study of The Relationship between Firms'lintellectual Capital, Financial Performance and Market Value." Journal of Intellectual Capital, 18(4), 771788.

Venugopal, D. and Subha, M. V. (2015). "Impact of Intellectual Capital on Corporate Performance."

Vladimir Dzenopoljac, Chadi Yaacoub, Nasser Elkanj, N. B. (2017). Article information: Impact of intellectual capital on corporate performance: Journal of Intellectual Capital, 18(4), 884903. 